\title{
Factors Affecting Agrobacterium-mediated Transformation of Common Bean
}

\author{
Zhanyuan Zhang ${ }^{1}$, Dermot P. Coyne ${ }^{2}$, and Amitava Mitra ${ }^{3}$ \\ University of Nebraska-Lincoln, Lincoln, NE 68583

\begin{abstract}
AdDtTIOnal INDEX words. Agrobacterium tumefaciens, $\beta$-glucuronidase, GUS, dry edible bean, Phaseolus vulgaris, plant
\end{abstract} \\ regeneration
}

\begin{abstract}
AkstraCt. Factors influencing Agrobacterium tumefaciens-mediated transformation of common beans (Phaseolus vulgaris $L$.) were examined using an intron-containing $\beta$-glucuronidase (GUS) gene as a reporter system to develop a repeatable transformation protocol. Tissue culture procedures used were based on direct shoot organogenesis. Two $A$. tumefaciens strains-A2760 and EHA105-were used, with emphasis on the former due to its overall higher infection rate. Eleven common-bean genotypes were compared for susceptibility to strain A2760 or EHA105. The pinto bean 'Othello' was used extensively in testing different transformation conditions. Factors significantly affecting transformation rate were Agrobacterium $\times$ host interactions, explant maturity, preculture and cocultivation conditions, and selection schemes, based on transient GUS gene expression. The best transformation conditions were the use of susceptible genotypes and explants derived from mature seeds, preconditioning of explants in a medium containing $20 \mu$ mol of benzyladenine (BA) in darkness or on a filter paper, dipping explants in high concentrations of Agrobacterium cell suspension $\left(\mathrm{OD}_{650}=0.8-\right.$ 1.0) followed by a long-term (6-day) cocultivation period on a semisolid agar medium in the presence of cytokinin or 3day cocultivation on a moistened filter paper, and the use of lethal levels of selective agents. About $4 \%$ of explants, or 14 $\%$ of regenerated shoots or buds, were putatively transgenic, as indicated by GUS blue staining throughout the entire shoot or bud, after explants were transformed with Agrobacterium strain A2760 using an optimized protocol.
\end{abstract}

Agrobacterium tumefaciens-mediated DNA transfer has been successfully explored for transformation of many dicots, including some leguminous crops such as soybean (Glycine max Mer.) (Chee et al., 1989; Falco et al., 1995; Hinchee et al., 1988), peanut (Arachis hypogaea L.) (Eapen and George, 1994), and pea (Pisum sativum L.) (Grant et al., 1995; Puonti-Kaerlas et al., 1990; Schroeder et al., 1993). This DNA delivery system has been used to introduce insect tolerance into pea (Shade et al., 1994).

Common bean (Phaseolus vulgaris L.) is an important food legume worldwide. The development of an efficient gene transfer system would greatly benefit breeding programs and enhance research investigating molecular processes. Although considerable efforts have been made (Franklin et al., 1993; Lewis and Bliss, 1994; Mariotti et al., 1989; McClean et al., 1991), an Agrobacterium-mediated transformation system has not yet been developed.

The slow progress in $P$. vulgaris transformation using $A$. tumefaciens delivery is attributed to lack of knowledge about factors affecting transformation. Only host $\times$ Agrobacterium interactions, effects of acetosyringone, and types of explant tissues on common-bean transformation have been reported previously (Lewis and Bliss, 1994; McClean et al., 1991). More research is needed on factors affecting $A$. tumefaciens-mediated transformation in common beans to develop a successful transformation scheme.

Received for publication 28 Aug. 1996. Accepted for publication 13 Dec. 1996. We thank Eugene Nester for providing the original GUS intron-containing construct and Paul $\mathrm{E}$. Read for providing experimental material necessary for common-bean plant tissue culture work. We also thank Anne K. Vidaver, Stephen G. Ernst, and Thomas E. Clemente for reviewing this manuscript. This research was supported by AID contract no. DNA-1310-G-SS-6008-00 and conducted under project 20036, Dept. of Horticulture, the WT/60 Program, and a minigrant (1-8001) from the Center for Biotechnology, Univ. of Nebraska, Lincoln. Published as Nebraska Agricultural Research Division journal series paper no. 11623. The cost of publishing this paper was defrayed in part by the payment of page charges. Under postal regulations, this paper therefore must be hereby marked advertisement solely to indicate this fact.

'Dept. of Horticulture; to whom reprint requests should be addressed. Present address: E325, Plant Transformation Facility, George W. Beadle Center, Univ. of Nebraska-Lincoln, Lincoln, NE 68588-0665. (hort045@unlvm.unl.edu).

${ }^{2}$ Dept, of Horticulture.

${ }^{3}$ Dept. of Plant Pathology and Center for Biotechnology.
The use of an intron-containing $\beta$-glucuronidase (GUS) reporter gene (Vancanneyt et al., 1990) has greatly facilitated analysis of transformation events in many other plant species. This assay system has at least two major advantages. It allows in situ analysis and quantification of transformation events by directly observing GUS blue sectors in explant tissues. False readings caused by $A$. tumefaciens contamination are eliminated due to the presence of an intron in the GUS coding region.

Therefore, our research objective was to investigate factors influencing $A$. tumefaciens-mediated DNA transformation of $P$. vulgaris using the GUS reporter gene system to develop a repeatable transformation protocol.

\section{Materials and Methods}

BinaRY VeCTOR AND aGRoBacterIUM. The original P35S GUS INT plasmid (Vancanneyt et al., 1990) containing the second intron(IV2) of the ST-LS1 gene was provided by Eugene W. Nester (Dept. of Microbiology, Univ. of Washington). The GUS INT region is flanked by the $35 \mathrm{~S} 5$ ' promoter and the $35 \mathrm{~S} 3$ ' terminator (about $3 \mathrm{~kb}$ ). This GUS INT cassette has been subcloned into the Hind III site of the binary vector B-28 (A. Mitra, unpublished data). The B-28 binary vector carries a $n p t$ II cassette in the T-DNA borders (Fig. 1). The B-28 vector without the P35S GUS INT fragment was used as a negative control. Thus, B-28/35S GUS INT and B-28 vectors were tested for GUS positive and negative activities in plant cells, respectively, either by electroporating them into tobacco protoplasts or by bombarding them into bean tissues using a biolistic PDS $/ 1000 \mathrm{He}$ device (BioRad). These two vectors were subsequently mobilized into $A$. tumefaciens strains A2760 (Hoekema et al., 1983) and EHA105 (Hood et al., 1993), respectively, by direct DNA transformation (An et al., 1988). The absence of GUS expression of B-28/P35S GUS INT vector in the A. tumefaciens cells was confirmed by testing for the absence of GUS activity in transformed $A$. tumefaciens cells compared with a GUS-positive reaction in transformed tobacco protoplasts under the same testing conditions.

Plant material and Regeneration procedures. Common- 
BamH I

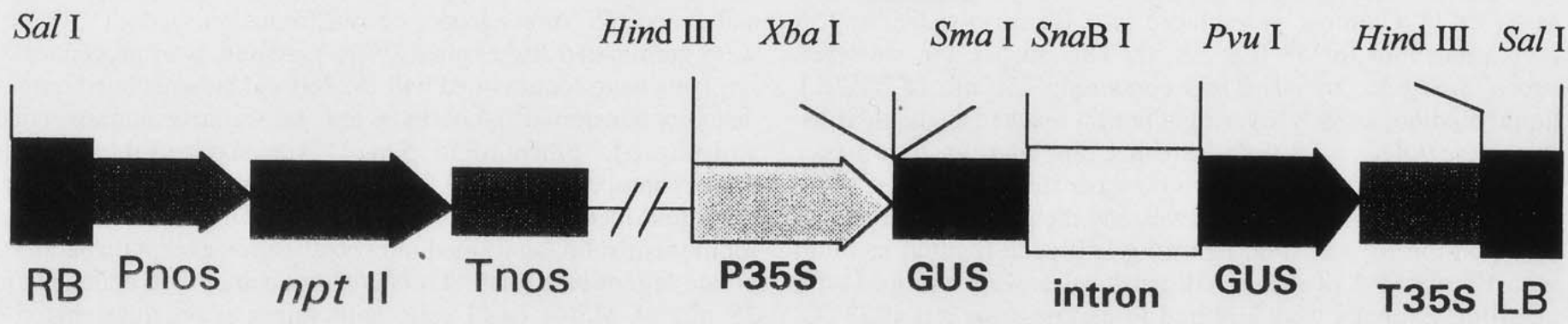

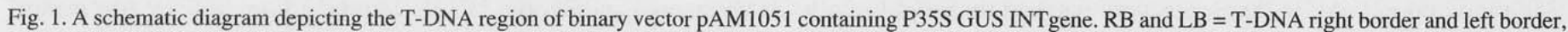

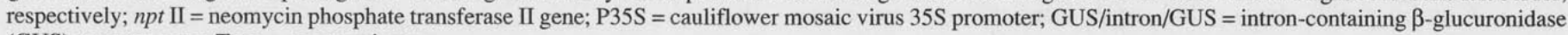
(GUS) reporter gene; Tnos $=$ nos terminator.

bean genotypes of Andean (A) and Meso-American (MA) origins were provided by James Steadman (Dept. of Plant Pathology, Univ. of Nebraska, Lincoln). Seeds of pinto 'Othello', great northern (GN) 'Harris', Alubia 33-1, Instituto Colombiano Agropecuario (ICA) 'Pijao', and Cranberry were planted in the greenhouse to obtain seeds for transformation experiments.

Plant regeneration was based on a direct shoot organogenesis protocol previously described by Mohamed et al. $(1991,1992)$ with some modifications. Explants were prepared using three different procedures. In procedure 1, mature healthy seeds of uniform sizes from different bean genotypes were disinfested for $20 \mathrm{~min}$ in $20 \%(\mathrm{v} / \mathrm{v})$ commercial bleach $(5.25 \% \mathrm{NaOCl})$ plus a few drops of Tween-20 and rinsed five times with sterile water. Seeds

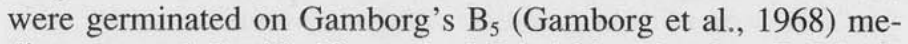
dium, amended with $10 \mu \mathrm{mol}$ of BA (abbreviated as $\mathrm{B}_{5} \mathrm{BA} 10$ ) (Table 1), solidified with $8 \mathrm{~g} \cdot \mathrm{L}^{-1}$ Difco Bacto agar, and adjusted to pH 5.8 before autoclaving for $20 \mathrm{~min}$. Each disinfested seed was placed in a $2 \times 15-\mathrm{cm}$ Pyrex tube (Scientific Products Division, Baxter Diagnostics Inc., McGaw Park, Ill.) containing $5 \mathrm{~mL}$ of $\mathrm{B}_{5} \mathrm{BA} 10$ medium. Cultures were incubated in a 16 -h photoperiod $\left(40 \mu \mathrm{mol} \cdot \mathrm{m}^{-2} \cdot \mathrm{s}^{-1}\right.$ from cool-white fluorescent tubes) at $25^{\circ} \mathrm{C}$ for 2 to 3 weeks or until axillary shoots or buds emerged. Seedling node explants were prepared by removing epicotyl and hypocotyl sections and two-thirds of each cotyledon. Nodal regions were then lightly scratched or macerated ( 5 to 10 parallel slices $0.5 \mathrm{~mm}$ deep vertical to the sliced region) with a no. 10 sterile scalpel blade after the emerging axillary shoots or buds were removed. In procedure 2 , disinfested seeds were germinated on a sterile moistened filter paper in $1.5 \times 10$-cm petri dishes at $25^{\circ} \mathrm{C}$ for 1 week under a 16 - h photoperiod until green hypocotyls appeared. Explants were then prepared with a no. 10 scalpel blade by following sequential steps: a) only 3 to $5 \mathrm{~mm}$ of the hypocotyl region adjacent to the nodal region was retained, b) then each seed was split in half by cutting through the hypocotyl region, and c) the whole epicotyl region and all vascular tissues of the nodal region were removed. The explant was then wounded as in procedure 1 . In procedure 3 , immature bean seeds were isolated from green pods, about $21 \mathrm{~d}$ postflowering, and disinfested as described above. Seedcoats were removed and explants were prepared as described in procedure 2 except that no hypocotyl region was retained.

The explants prepared using these three different procedures were cultured in $1.5 \times 10-\mathrm{cm}$ petri dishes (six explants per petri dish), abaxial side in contact with the shoot induction medium $\mathrm{B}_{5} \mathrm{BA} 10$ (Table 1). Cultures were grown at $25^{\circ} \mathrm{C}$ under a $16-\mathrm{h}$ photoperiod $\left(40 \mu \mathrm{mol} \cdot \mathrm{m}^{-2} \cdot \mathrm{s}^{-1}\right.$ from cool-white fluorescent tubes) for 2 to 3 weeks or until shoots emerged. Shoots longer than $1 \mathrm{~cm}$ were excised and transferred to Gamborg's $\mathrm{B}_{5}$ basal medium (Gamborg et al., 1968) without BA for rooting. Explants, after their shoots were removed, were transferred to a fresh shoot induction medium containing Murashige and Skoog (MS) basal salts (Murashige and Skoog, 1962) and $B_{5}$ vitamins amended with $10 \mu \mathrm{mol}$ BA (abbreviated as $\mathrm{MSB}_{5}+\mathrm{BA} 10$ ). All tissue culture media and reagents were purchased from Sigma Co., St. Louis, unless otherwise stated.

Transformation Procedures. A single colony of $A$. tumefaciens strain A2760 or EHA105, containing B-28/GUS INT or B28 , was inoculated into $5 \mathrm{~mL}$ of yeast extract and peptone (YEP) (Difco Laboratories, Detroit) liquid medium supplemented with

Table 1. Tissue culture media, hormonal concentrations $(\mu \mathrm{mol})$, and antibiotics $\left(\mathrm{mg} \cdot \mathrm{L}^{-1}\right)$ used for seed germination, cocultivation, shoot induction, and postcocultivation selection of common bean ${ }^{2}$.

\begin{tabular}{|c|c|}
\hline Media-procedure & Media-procedure-selection \\
\hline Seed germination & Shoot induction-selection \\
\hline $\mathrm{B}_{5}+\mathrm{BA} 10$ & $\mathrm{~B}_{5}$ or $\mathrm{MSB}_{5},+\mathrm{BA} 10$ \\
\hline $\mathrm{B}_{5}+\mathrm{BA} 20$ & $\mathrm{~B}_{5}+\mathrm{BA} 10+\mathrm{Kan} 25+\mathrm{Carb} 200+\operatorname{Cef} 200$ \\
\hline $\mathrm{B}_{5}+\mathrm{BA} 30$ & $\mathrm{~B}_{5}+\mathrm{BA} 10+\mathrm{Kan} 50+\mathrm{Carb} 200+$ Cef 200 \\
\hline Filter paper & $\mathrm{B}_{5}+\mathrm{BA} 10+\mathrm{Kan} 75+\mathrm{Carb} 200+\operatorname{Cef} 200$ \\
\hline Cocultivation & $\mathrm{B}_{5}+\mathrm{BA} 10+\mathrm{Kan} 100+\mathrm{Carb} 200+\mathrm{Cef} 200$ \\
\hline $\mathrm{MS}$ or $\mathrm{B}_{5},+\mathrm{BA} 10$ & $\mathrm{~B}_{5}+\mathrm{BA} 10+\mathrm{Kan} 125+\mathrm{Carb} 200+\mathrm{Cef} 200$ \\
\hline $\mathrm{MS}+2,4-\mathrm{D}, 20$ & $\mathrm{~B}_{5}+\mathrm{BA} 10+\operatorname{Tim} 60$ \\
\hline MS(-), liquid & Rooting-selection \\
\hline $\mathrm{B}_{5}(-)+\mathrm{BA} 20$, liquid & $\mathrm{B}_{5}+\mathrm{Kan} 50$ \\
\hline Filter paper & \\
\hline
\end{tabular}

$\overline{{ }^{\mathrm{Z}} \mathrm{Kan}}=$ kanamycin Carb = carbenicillin; Cef = cefotaxime; Tim = timentin; $\mathrm{BA}=$ benzyladenine; MS $=$ Murashige and Skoog (1962) basal medium; $\mathrm{B}_{5}=$ Gamborg et al. (1968) $\mathrm{B}_{5}$ basal medium; $\mathrm{MSB}_{5}=$ MS (Murashige and Skoog, 1962) salts, and $\mathrm{B}_{5}$ (Gamborg et al., 1968) vitamins. 
$10 \mathrm{mg} \cdot \mathrm{L}^{-1}$ of kanamycin and $5 \mathrm{mg} \cdot \mathrm{L}^{-1}$ of tetracycline (abbreviated as YEPKT). Cultures were placed on a platform shaker at 150 revolutions/min for $48 \mathrm{~h}$ at $28^{\circ} \mathrm{C}$. This suspension was then subcultured once in 1-L flasks containing $250 \mathrm{~mL}$ of YEPKT liquid medium at $28^{\circ} \mathrm{C}$ overnight until it reached a late logarithmic phase $\left(\mathrm{OD}_{640}=0.8-1.0\right)$. Explants, ranging from 20 to 40 per replication, were soaked in strain suspensions for 5 to $15 \mathrm{~min}$, blotted dry on a sterile paper towel, and then placed abaxial side down on the $\mathrm{B}_{5}$ semisolid agar $\left(6 \mathrm{~g} \cdot \mathrm{L}^{-1}\right)$ cocultivation medium with $10 \mu \mathrm{mol}$ BA (Table 1). All petri dishes were wrapped with parafilm. Explants were cultured in darkness for $3 \mathrm{~d}$ at $28^{\circ} \mathrm{C}$. Following cocultivation, explants were washed thoroughly with $B_{5}(-)$ (Gamborg's $B_{5}$ basal salts with minimal organic compounds, pH 5.8) liquid medium and stained with $\mathrm{X}$-gluc solution (see the following section for GUS staining procedures). However, some parameters for transformation procedures were varied.

To study the effect of dark preconditioning and cytokinin(BA) on $A$. tumefaciens infection rate and GUS gene expression, seeds were germinated either in darkness or $16 \mathrm{~h}$ photoperiod (40 $\mu \mathrm{mol} \cdot \mathrm{m}^{-2} \cdot \mathrm{s}^{-1}$ from cool-white fluorescent tubes) at $25^{\circ} \mathrm{C}$ on the $\mathrm{B}_{5}$ medium supplemented with 10,20 , or $30 \mu \mathrm{mol} \mathrm{BA}$ (Table 1) until shoot buds emerged (14 to $21 \mathrm{~d}$ ). Explants were prepared following procedure 1 and then cocultivated with strain A2760.

To test for susceptibility of bean genotypes to A. tumefaciens strains, seeds of 'Othello' and 'PC50' were germinated and explants were prepared according to procedure 1. Explants were then cocultivated with A2760 and EHA105, respectively. Additional equal numbers of explants of these two genotypes were cocultivated with A2760 and EHA105 that contained only B-28 without the GUS intron as a negative control under the same experimental conditions. After cocultivation, explants were transferred to shoot induction-selection medium $\left(\mathrm{B}_{5}+\mathrm{BA} 10+\mathrm{Kan} 25+\mathrm{Carb} 200+\right.$ Cef 200) (Table 1). Explants were stained with X-gluc $21 \mathrm{~d}$ following culturing selection. The same procedures were used to screen nine additional bean genotypes except that only A2760 was used.

To examine the effect of explant maturity on transformation efficiency, bean genotypes Alubia 33-1, ICA 'Pijao', and pinto 'Othello' were planted and grown as described above, and immature cotyledonary explants were prepared according to procedure 3. Mature explants were prepared according to procedure 2 . Freshly prepared explants were then cocultured with A2760.

To examine the effects of plant growth regulators present in the cocultivation media, mature seeds of pinto 'Othello' and GN 'Harris' were germinated on moistened filter papers in $1.5 \times 10$-cm petri dishes at 25 ${ }^{\circ} \mathrm{C}$ for $8 \mathrm{~d}$ at a 16 -h photoperiod $\left(40 \mu \mathrm{mol} \cdot \mathrm{m}^{-2} \cdot \mathrm{s}^{-1}\right.$ from cool-white fluorescent tubes). Explants from seeds were prepared as in procedure 2 , immersed in the A2760 cell suspension for 5 to $15 \mathrm{~min}$, and cocultivated on filter paper or on MS medium in the presence of either cytokinin $(10 \mu \mathrm{mol} \mathrm{BA})$ or auxin (20 $\mu \mathrm{mol} 2,4-\mathrm{D})$ (Table 1).

Fig. 2. Effect of dark preconditioning and cytokinin [benzyladenine BA)] concentrations on infection rate of the common-bean genotype 'Othello'. Data are least square means from two replications. Each bar represents standard error of a least squares (ls) mean. No error bar was presented for each column in the light treatment due to the zero infection. Treatment Ismeans with the same letters are not significantly different as determined by Duncan's multiple range test (DMRT) at $P \leq 0.05$.
To study the effect of types of cocultivation media, explant age, and postcocultivation selection on transformation, seeds of 'Othello' were germinated and explants were prepared as in procedure 2 . Explants were cocultivated with A2760 and either stained immediately or transferred to shoot induction-selection medium amended with $60 \mathrm{mg} \cdot \mathrm{L}^{-1}$ timentin and $75 \mathrm{mg} \cdot \mathrm{L}^{-1}$ kanamycin (Table 1 ) under a 16-h photoperiod for $21 \mathrm{~d}$, followed by staining for GUS activity. For liquid-medium cocultivation, all procedures were the same as for the semisolid (agar) medium cocultivation except that $250 \mu \mathrm{L}$ of late-logarithmic phase $A$. tumefaciens culture was added to the $25 \mathrm{~mL}$ of MS(-) basal salts with minimal organics, $\mathrm{pH} 5.8$ (Murashige and Skoog, 1962), liquid medium in $1.5 \times 10-\mathrm{cm}$ petri dishes.

Lethal and sublethal concentrations of kanamycin were determined based on a dosage-response experiment (data not shown) using $\mathrm{B}_{5}+\mathrm{BA} 10$ medium with various concentrations of kanamycin (Table 1.).

Gus staINING. The GUS staining solution used throughout all experiments included $0.5 \mathrm{mg} \cdot \mathrm{mL}^{-1} \mathrm{X}$-gluc (cyclohexylammonium salt) (Gold Biotechnology, Inc., St. Louis), $0.5 \%$ (v/v) Triton-100, $80 \%$ of $50 \mathrm{mmol} \mathrm{NaPO}_{4}(\mathrm{pH} 7.0)(\mathrm{v} / \mathrm{v})$, and $20 \%(\mathrm{v} / \mathrm{v})$ methanol anhydrate (stored at $-20^{\circ} \mathrm{C}$ ) (Thomas et al., 1992). Before adding the GUS staining solution, explants were washed once with 0.4 mol mannitol and then with $100 \mathrm{mmol} \mathrm{NaPO}$. After the staining solution was added, explants were incubated at $37^{\circ} \mathrm{C}$ in darkness until GUS blue sectors were visible (about 5 to $12 \mathrm{~h}$ ) and destained with $70 \%$ ethanol. Several changes of $70 \%$ ethanol were necessary to eliminate chlorophyll. Explants were subsequently examined for GUS expression with a dissecting microscope.

INFECTION RATE. GUS activity was determined by the histochemical method as described above and expressed as GUS blue sectors. An explant was considered infected if there was at least one GUS blue sector. In a few studies, infection rates were estimated by observing the GUS blue sector in only certain tissues. Levels of GUS expression, when compared, were evaluated based on the number of GUS blue sectors per explant. Therefore, the infection rates were calculated using the number of infected explants divided by the total number of explants for each replicate. Factorial or split-plot designs, either in a completely random design or in randomized complete-block arrangements, were used

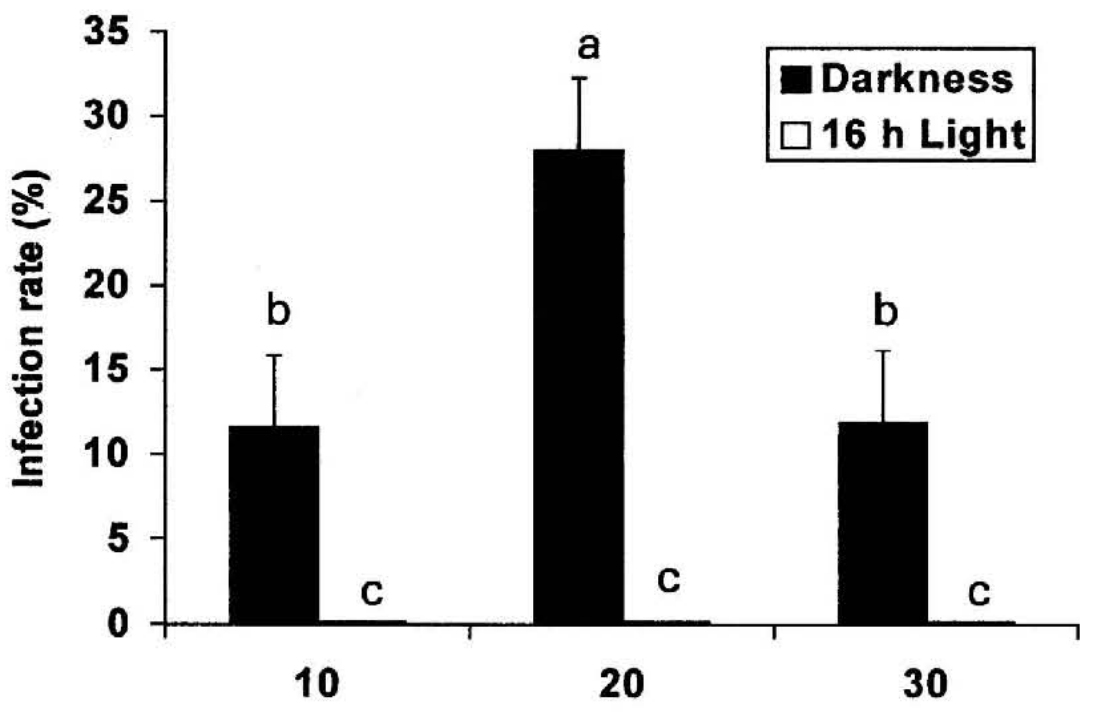

BA concentration ( $\mu \mathrm{mol})$ 
with at least two replications in each experiment. Means were presented as least square means (lsmeans) due to some missing data. Duncan's multiple range tests (DMRTs) or protected LSDS were used for mean comparisons only when $F$ test showed statistical significance $(P \leq 0.05)$.

\section{Results and Discussion}

DARK PRECONIDTIONING AND PRECULTURE OF EXPLANT SEEDLINGS WITH CYTOKININ. Culturing seedling node explants in darkness before cocultivation increased $A$. tumefaciens infection rates $(P \leq 0.001)$ compared to those grown under light treatment (Fig. 2 ). In addition, various levels of BA affected infection rate, with $20 \mu \mathrm{mol}$ being optimal. Pretreating explants with different growth regulators also influenced gene transfer in other crops (Akama et al., 1992; Bondt et al., 1994; Jacq et al., 1993; Janssen and Gardner, 1993; Li et al., 1992; Sangwan et al., 1991). Initially, it was presumed that seed germination and preculturing seedlings in darkness might increase explant susceptibility to Agrobacterium, because etiolated seedlings had thinner cell walls and cuticles. This treatment could also affect chemical composition of the seedlings and was also reported to promote shoot organogenesis (Mohamed et al., 1992). The dark treatment was then used in all subsequent experiments unless otherwise specified.

SUSCEPTIBILITY OF BEAN CULTIVARS TO AGROBACTERIUM STRAINS. Preliminary screening for Agrobacterium-host compatibility using A2760 and EHA 105 included two bean genotypes-'PC50'
(A) and 'Othello' (MA). The strain EHA105 induced fewer GUS blue sectors than A2760 on both bean genotypes $(P \leq 0.05)$ (Table 2). 'PC50' was more susceptible than 'Othello' to both strains. Infection rates, however, were not different either between the two bean genotypes or between the two Agrobacterium strains, based on percentage of chimeric shoots with GUS blue sectors (data not shown). This was due to higher infection of cotyledons with strain A2760 than with strain EHA105. No significant interactions were detected between strains and genotypes $(P>0.05)$ for infection rate on cotyledonary tissues. No difference in infection was observed between strains for meristematic nodal regions; which were involved in direct shoot regeneration in our protocols. However, because of its greater infection ability, strain A2760 was chosen for use in the remaining experiments.

Using the same transformation procedure as above, nine additional bean genotypes were screened as follows: navy bean 'Seafarer', black bean ICA 'Pijao', red bean Zamorano, black bean 'Compuesto Nigra Chimaltenango', pink bean Red Mexican 235, red bean Garbancillo Zarco G15821, black bean Bolita (all MA), white bean Alubia 33-1, and cranberry bean (both A) origin. They represented centers of subdomestication of MA and A origins, respectively (Schoonhoven and Voysest, 1991; Skroch et al., 1992). Susceptibility (as determined by infection rate) of these genotypes to strain $\mathrm{A} 2760$ was significantly different $(P \leq 0.05)$ as determined by protected LSD. All MA bean genotypes were not infected by this strain (no infection) except for ICA 'Pijao' and G15821, which showed $3.9 \%$ and $6.3 \%$ infection rates, respec-

Table 2. Host $\times$ Agrobacterium tumefaciens interaction between two common bean genotypes and Agrobacterium strains.

\begin{tabular}{|c|c|c|c|c|}
\hline \multirow[b]{2}{*}{$\begin{array}{l}\text { Agrobacterium } \\
\text { strains }\end{array}$} & \multicolumn{2}{|c|}{ PC 50} & \multicolumn{2}{|c|}{ Pinto Othello } \\
\hline & $\begin{array}{l}\text { Infection } \\
\text { rate }(\%)^{z}\end{array}$ & $\begin{array}{l}\text { No. GUS sectors } \\
\text { per explant }\end{array}$ & $\begin{array}{l}\text { Infection } \\
\text { rate }(\%)\end{array}$ & $\begin{array}{c}\text { No. GUS sectors } \\
\text { per explant }\end{array}$ \\
\hline$\overline{\mathrm{A} 2760}$ & $84.4 \mathrm{a}(13.6)$ & $9.8(1.1)$ & $51.9 \mathrm{~b}(17.5)$ & $4.6(1.2)$ \\
\hline EHA105 & $48.1 \mathrm{~b}(13.6)$ & $4.2(1.4)$ & $21.8 \mathrm{c}(13.6)$ & $2.8(1.3)$ \\
\hline
\end{tabular}

${ }^{2}$ Data are least square (1s) means and from three replications. Numbers with the same letters are not significantly different $(P>0.05)$ as determined by protected L.SD. The numbers within parenthesis indicate the standard error of a lsmean. GUS $=\beta$-glucuronidase.

Table 3. Effect of explants, derived from either mature or immature seeds, of three common bean genotypes on infection rate and $\beta$-glucuronidase (GUS) gene expression.

\begin{tabular}{lccccc}
\hline \hline & \multicolumn{2}{c}{ Immature explant } & & \multicolumn{2}{c}{ Mature explant } \\
\cline { 2 - 3 } \cline { 5 - 6 } Bean genotypes & $\begin{array}{c}\text { Infection } \\
\text { rate }(\%)^{2}\end{array}$ & $\begin{array}{c}\text { No. GUS sectors } \\
\text { per explant }{ }^{2}\end{array}$ & & $\begin{array}{c}\text { Infection } \\
\text { rate }(\%)\end{array}$ & $\begin{array}{c}\text { No. GUS sectors } \\
\text { per explant }\end{array}$ \\
\hline Alubia & $51.1 \mathrm{~b}(0.63)$ & $19.9(12.9)$ & & $85.3 \mathrm{a}(0.96)$ & $148.6(12.9)$ \\
Pinto Othello & $6.3 \mathrm{~d}(0.63)$ & $2.5(0.7)$ & & $42.8 \mathrm{c}(0.96)$ & $21.5(21.2)$ \\
ICA Pijao & $0.0 \mathrm{f}(0.00)$ & $0.0(0.0)$ & & $4.0 \mathrm{e}(0.96)$ & $0.7(2.7)$
\end{tabular}

${ }^{2}$ Least square (ls) means of a duplicate. Numbers followed by different letters indicate a significant difference $(P \leq 0.05)$ as determined by DMRT. The numbers within parenthesis indicate the standard error of a lsmean.

Table 4. Effect of cytokinin (BA), auxin (2,4-D), and filter paper on $\beta$-glucuronidase (GUS) expression during cocultivation of two common bean genotypes with Agrobacterium tumefaciens strain A2760.

\begin{tabular}{|c|c|c|c|c|}
\hline \multirow[b]{2}{*}{ Treatments } & \multicolumn{2}{|c|}{ Great northern Harris } & \multicolumn{2}{|c|}{ Pinto Othello } \\
\hline & $\begin{array}{l}\text { Infection } \\
\text { rate }(\%)^{z}\end{array}$ & $\begin{array}{l}\text { No. GUS sectors } \\
\text { per explant }\end{array}$ & $\begin{array}{l}\text { Infection } \\
\text { rate }(\%)\end{array}$ & $\begin{array}{c}\text { No. GUS sectors } \\
\text { per explant }\end{array}$ \\
\hline$\overline{\mathrm{BA}}, 10 \mathrm{mM}$ & $19.4 \mathrm{~b}$ & $1.4(2.4)$ & $24.0 \mathrm{~b}$ & $2.6(2.0)$ \\
\hline $2,4-\mathrm{D}, 20 \mathrm{~mm}$ & $0.0 \mathrm{a}^{\circ}$ & $0.0(0.0)$ & $14.0 \mathrm{a}$ & $2.0(2.6)$ \\
\hline Filter paper & $40.0 \mathrm{c}$ & $3.3(1.6)$ & $50.0 \mathrm{c}$ & $23.6(2.1)$ \\
\hline
\end{tabular}

${ }^{\mathrm{z}}$ Least square (ls) means of three replications. Numbers with the same letters within a column are not significantly different $(P$ $>0.05$ ) as determined by DMRT. The numbers within parenthesis indicate the standard error of a ismean. 
tively. The two A genotypes were more susceptible to the strain than the MA genotypes, with Alubia 33-1 being most susceptible $(85.7 \%)$ and cranberry bean ranked second $(41.4 \%)$.

EXPLANT MATURITY. Mature and immature explants were prepared from three susceptible genotypes as determined above following procedures 2 and 3 , respectively. A significant interaction $(P \leq 0.001)$ between genotypes and explant maturity was also found, suggesting that the susceptibility of different bean genotypes changed with maturity (Table 3 ). Strain A2760 induced higher infection rates $(P \leq 0.001)$ on mature than immature explants of all three genotypes. The GUS activity, as determined by the number of GUS blue sectors, also showed higher levels in mature than in immature explants. This effect of maturity has not been reported previously.

EFFECT OF PLANT GROWTH REgULATORS IN COCULTIVATION MEDIA. Gene transfer could be inhibited by auxin (Li et al., 1992) and enhanced by cytokinin (Bondt et al., 1994) and filter paper (Janssen and Gardner, 1993). Filter papers were superior for inducing-GUS activity, whereas auxin (2,4-D) reduced the infection rate and GUS gene expression (Table 4). Explants cocultivated on filter paper also showed more GUS blue sectors than those on other cocultivation media. The reason for the enhanced GUS expression from the control treatment on filter paper is not clear. It is possible that the phosphate starvation of Agrobacterium cells (Aoyama et al., 1991; Li et al., 1994), due to the lack of nutrient supply on the filter paper, enhanced DNA transfer.

TYPE OF COCULTIVATION MEDIUM, EXPLANT AGE, AND SELECTION SCHEME. Two media for cocultivation, liquid and semisolid (Table 1), were examined across two different explant ages and selection schemes for their effects on infection rate and GUS gene expression using procedure 2 for explant preparation. In spite of no difference in explant survival rate (data not shown), the percentage of explants expressing GUS activity cocultivated on the semisolid medium was significantly higher over two explant ages (Table 4). In contrast, explants cocultivated in liquid medium did not show any Agrobacterium infection when no selection pressure was imposed. These results confirm previous findings in peanut cocultivation where transformation efficiency was greater on a semisolid medium than on a liquid medium(Mansur et al., 1993). Additionally, 8-d-old explants were consistently found to be more susceptible to strain A2760 than 4-d-oldexplants $(P \leq 0.05)$, nomatter whether ornotapostcocultivation selection was imposed. On the other hand, kanamycin $\left(75 \mathrm{mg} \cdot \mathrm{L}^{-1}\right)$ in the medium enhanced the recovery of transformed cells significantly $(P \leq 0.05)$. This was also demonstrated by Hinchee et al. (1988) in soybean transformation, even when liquid coculture medium was used (see also Table 5). We consider this kanamycin concentration lethal, based on our dosage response study in which $25 \mathrm{mg} \cdot \mathrm{L}^{-1}$ of kanamycin bleached $75 \%$ of shoots, whereas $50 \mathrm{mg} \cdot \mathrm{L}^{-1}$ of kanamycin completely prevented shoot formation of common bean cotyledons (data not shown).

Length of Cocultivation. The length of cocultivation required for achieving maximum gene transfer was genotype dependent, ranging with most plant species from 2 to $5 \mathrm{~d}$. The highest infection rate was observed at $6 \mathrm{~d}$ at $25^{\circ} \mathrm{C}$ and at $8 \mathrm{~d}$ at $28^{\circ} \mathrm{C}$. When explants were cocultivated for $6 \mathrm{~d}$ at $25^{\circ} \mathrm{C}$ in darkness, $4 \%$ of the explants, or $14.3 \%$ of the shoots or buds, showed GUS activity throughout the entire bud. Explant survival rate was reduced in darkness (Zhang, 1996), but increased even in dim light during the cocultivation periods (data not shown). Dim light also greatly enhanced shoot and bud induction without reducing transformation rates during this 6-d period (data not shown).

In general, the higher $A$. tumefaciens infection rates also corresponded to the higher levels of GUS activity, as evaluated by the number of GUS blue sectors. Apparently, little infection occurred in meristematic areas compared with cotyledonary tissues. The reason for this difference is not clear. Because only meristematic regions are competent for shoot regeneration of $P$. vulgaris using direct organogenesis, increasing infection in these regions was critical and, therefore, was our main concern throughout this investigation. This was eventually accomplished using optimized procedures that have not been reported previously. Thus, the recommended overall procedures for transforming common bean should include 1) using susceptible genotypes and explant tissues derived from mature seeds, 2) germinating seeds on B $_{5}$ BA20 agar medium for 2 weeks in darkness or on a moistened filter paper for 1 week in a 16-h photoperiod, 3) thoroughly wounding explant tissues at nodal regions following the explant preparation procedures as described above, 4) dipping explants in logarithmic phase $\left(\mathrm{OD}_{650}=0.8-1.0\right)$ of $A$. tumefaciens cell suspension for 5 to $15 \mathrm{~min}$, blotting dry on a paper towel, followed by a 6-d cocultivation on the $\mathrm{B}_{5}$ agar medium in the presence of $\mathrm{BA}$, or a 3-d cocultivation on a moistened filter paper (only for explants germinated on filter papers) in a dim light, 5) culturing explants on a postcocultivation selection medium ( $\left.\mathrm{B}_{5} \mathrm{BA} 10\right)$ containing lethal concentrations of selection reagents ( $75 \mathrm{mg} \cdot \mathrm{L}^{-1}$ kanamycin in our case), and transferring antibiotic resistant shoots $\left(0.5 \mathrm{~cm}\right.$ in length) into $\mathrm{B}_{5}$ rooting medium with reduced concentrations of selective agents (e.g., 50 $\mathrm{mg} \cdot \mathrm{L}^{-1}$ kanamycin or lower).

Table 5. Effect of types of cocultivation media, explant age, and postcocultivation selection on infection rate and $\beta$-glucuronidase (GUS) gene expression of common bean genotype 'Othello'.

\begin{tabular}{|c|c|c|c|c|c|}
\hline \multirow[b]{2}{*}{$\begin{array}{l}\text { Medium } \\
\text { type }\end{array}$} & \multirow[b]{2}{*}{$\begin{array}{c}\text { Explant } \\
\text { age }\end{array}$} & \multicolumn{2}{|c|}{$\begin{array}{c}\text { GUS staining } 0 \mathrm{~d} \\
\text { postcocultivation, } \mathrm{K}_{0}{ }^{2}\end{array}$} & \multicolumn{2}{|c|}{$\begin{array}{c}\text { GUS staining } 21 \mathrm{~d} \\
\text { postcocultivation, } \mathrm{K}_{75}{ }^{\mathrm{y}}\end{array}$} \\
\hline & & $\begin{array}{l}\text { Infection } \\
\text { rate }(\%)^{x}\end{array}$ & $\begin{array}{l}\text { No. GUS sectors } \\
\text { per explant }\end{array}$ & $\begin{array}{l}\text { Infection } \\
\text { rate }(\%)\end{array}$ & $\begin{array}{c}\text { No. GUS sectors } \\
\text { per explant }\end{array}$ \\
\hline \multicolumn{6}{|c|}{ B5, semi solid } \\
\hline & 4-d seedlings & $69.3 \mathrm{c}(5.4)$ & $15.9(3.4)$ & $83.1 \mathrm{~b}(5.4)$ & $31.1(3.1)$ \\
\hline & 8-d seedlings & $71.1 \mathrm{c}(8.2)$ & $19.7(3.7)$ & $100.0 \mathrm{a}(9.3)$ & $28.1(4.9)$ \\
\hline \multicolumn{6}{|c|}{ MS(-), liquid } \\
\hline & 4-d seedlings & $0 \mathrm{e}(0.0)$ & $0.0(0.0)$ & $9.8 \mathrm{~d}(9.3)$ & $2.1(7.4)$ \\
\hline & 8-d seedlings & $0 \mathrm{e}(0.0)$ & $0.0(0.0)$ & $69.8 \mathrm{c}(9.3)$ & $4.0(9.3)$ \\
\hline
\end{tabular}




\section{Literature Cited}

Akama, K., H. Shiraishi, S. Ohta, K. Nakamura, K. Okada, and Y. Shimura. 1992. Efficient transformation of Arabidopsis thaliana: comparison of the efficiencies with various organs, plant ecotypes and Agrobacterium strains. Plant Cell Rpt. 12:7-11.

An, G., P.R. Ebert, A. Mitra, and S.B. Ha. 1988. Binary vectors, p. 1-19. In: S.B. Gelvin, R.A. Schilperroort, and D.P. S. Verma (ed.). Plant molecular biology manual. Kluwer Academic Publishers, Dordrecht, The Netherlands.

Aoyama, T., M. Takanami, K. Makino, and A. Oka. 1991. Cross-talk between the virulence and phosphate regulons of Agrobacterium tumefaciens caused by an unusual interaction of the transcriptional activator with a regulatory DNA element. Mol. Gen. Genet. 227:385-390.

Bondt, A.D., K. Eggermont, P. Druart, M.D. Vil, I. Goderis, J. Vanderleyden, and W.E. Broekaert. 1994. Agrobacterium-mediated transformation of apple (Malus $\times$ domestica Borkh.): An assessment of factors affecting gene transfer efficiency during early transformation steps. Plant Cell Rpt. 13:587-593.

Chee, P.P., K.A. Fober, and J.L. Slightom. 1989. Transformation of soybean (Glycine max) by infecting germinating seeds with Agrobacterium tumefaciens. Plant Physiol. 91:1212-1218.

Eapen, S. and L. George. 1994. Agrobacterium tumefaciens mediated gene transfer in peanut (Arachis hypogaea L.). Plant Cell Rpt. 13:582586.

Falco, S.C., T. Guide, T. Guida, M. Locke, J. Mauvais, C. Sanders, R.T. Ward, and P. Webber. 1995. Transgenic canola and soybean seeds with increased lysine. Bio/Technology 13:577-582.

Franklin, C.I., T.N. Trieu, B.G. Cassidy, R.A. Dixon, and R.S. Nelson. 1993. Genetic transformation of green bean callus via Agrobacterium mediated DNA transfer. Plant Cell Rpt. 12:74-79.

Gamborg, O.L., R.A. Miller, and K. Ojima. 1968. Nutrient requirements of suspension cultures of soybean root cells. Expt. Cell. Res. 50:151158.

Grant, J.E., P.A. Cooper, AE. McAra, and T.J. Frew. 1995. Transformation of peas (Pisum sativum L.) using immature cotyledons. Plant Cell Rpt. 15:254-258.

Hinchee, M.A.W.,D.V.Connor-Ward, C.A.Newell, R.E. McDonnel, S.J. Sato, C.S. Gasser, D.A. Fischhoff, D.B. Re, R.T. Fraley, and R.B. Horsch. 1988. Production of transgenic soybean plants using Agrobacterium mediated DNA-transfer. Bio/Technology 6:915-922.

Hoekema, A., P.R. Hirsch, P.J.J. Hooykaas, and R.A. Schilperoort. 1983. A binary plant vector strategy based on separation of vir-and T-region of the Agrobacterium tumefaciens Ti-plasmid. Nature 303:179-181.

Hood, E., S.B. Gelvin, L. Melchers, and A. Hoekema. 1993. New Agrobacterium helper plasmids for gene transfer to plants. Transgenic Res. 2:208-218.

Jacq, B., O. Lesobre, R.S. Sangwan, and B.S. Sangwan-Norreel. 1993. Factors influencing tDNA transfer in Agrobacterium-mediated transformation of sugarbeet. Plant Cell Rpt. 12:621-624.

Janssen, B.J. and R.C. Gardner. 1993. The use of transient GUS expression to develop an Agrobacterium-mediated gene transfer system for kiwifruit. Plant Cell Rpt. 13:28-31.

Lewis, M.E. and F.A. Bliss. 1994. Tumor formation and $\beta$-glucuronidase expression in Phaseolus vulgaris inoculated with Agrobacterium tumefaciens. J. Amer. Soc. Hort. Sci. 119:361-366.

Li, X.B., Y.Y. Bai, Z.H. Xu, and Z.M. Wei. 1994. Study on the conditions of cell transformation in Astragalus sinicus. Acta Bot. Sinica 36:437443.

Li, X.Q., C.N.Liu, S.W. Ritchic, J.Y.Peng, S.B. Gelvin, and T.K. Hodges. 1992. Factors influencing Agrobacterium-mediated transient expression of GUSA in rice. Plant Mol. Biol. 20:1032-1048.

Mansur,E.A.,C.Lacorte, V.G. deFreitas, D.E. de Oliveira, B. Timmerman, and A.R. Cordeiro. 1993. Regulation of transformation efficiency of peanut (Arachis hypogaea L.) explants by Agrobacterium tumefaciens. Plant Sci. 89:93-99.

Mariotti, D., G.S. Fontana, and L. Santini. 1989. Genetic transformation of grain legumes: Phaseolus vulgaris $\mathrm{L}$. and $P$. coccineus $\mathrm{L}$. J. Genet. Breed. 43:77-82.

McClean, P.,P. Chee, B. Held, J. Simental, R.F. Drong, and J.L. Slightom. 1991. Susceptibility of dry bean (Phaseolus vulgaris L.) to Agrobacterium infection: Transformation of cotyledonary and hypocotyl tissues. Plant Cell Tiss. Org. Cult. 24:131-138.

Mohamed, F.M., P.E. Read, and D.P. Coyne. 1991. In vitro response of bean (Phaseolus vulgaris L.) cotyledonary explants to benzyladenine in the medium. PGRSA Quart 19:19-26.

Mohamed, M.F.,P.E. Read, and D.P. Coyne. 1992. Dark preconditioning, CPPU, and thidiazuron promote shoot organogenesis on seedling node explants of common and faba beans. J. Amer. Soc. Hort. Sci. 117:668 672.

Murashige, T. and F. Skoog. 1962. A revised medium for rapid growth and bioassay with tobacco tissue cultures. Physiol. Plant. 15:473-497.

Puonti-Kaerlas, J., T. Eriksson, and P. Engstrom. 1990. Production of transgenic pea (Pisum sativum L.) plants by Agrobacterium tumefaciens-mediated gene transfer. Theor. Appl. Genet. 80:246-252.

Sangwan, R.S., Y. Bourgeos, and B.S. Sangwan-Norreel. 1991. Genetic transformation of Arabidopsis thaliana zygotic embryos and identification of critical parameters influencing transformation efficiency. Mol. Gen. Genet. 230: 475-485.

Schoonhoven, A.V and O. Voysest. 1991. Common beans: Research for crop improvement, p. 1-980. CAB International, Cali, Colombia: CIAT.

Schroeder, H.E., A.H. Schotz, R.T. Wardley, D. Spencer, and T.J.V. Higgins. 1993. Transformation and regeneration of two cultivars of pea (Pisum sativum L.). Plant Physiol. 101:751-757.

Shade, R.E., H.E. Schroeder, J.J.Pueyo, L.M. Tabe, L.L. Murdock, T.J.V. Higgins, and M.J. Chrispeels. 1994. Transgenic pea seeds expressing the $\alpha$-amylase inhibitor of the common bean are resistant to bruchid beetles. Bio/Technology 12:793-796.

Skroch, P., T. Jan, and N. James. 1992. Analysis of genetic relationships using RAPD marker data. Proc. Symp. Appl. RAPD Technol. Plant Breed., Joint Plant Breed. Symp. Series, Crop Sci. Soc. Amer.-Amer. Soc. Hort. Sci.-Amer. Genet. Assn. p. 26-30.

Thomas, M., W. Rose-Valentina, H. Sabine, W. Lothar, and B.F. Wolf. 1992. The GUS reporter system as a tool to study plant gene expression, p. 23-43. In: S.R. Gallagher (ed.). GUS Protocols: Using the GUS gene as a reporter of gene expression. Academic Press, New York.

Vancanneyt, G., R. Schmidt, A. O'Connor-Sanchez, L. Willmitzer, and M. Rocha-Sosa. 1990. Construction of an intron-containing marker gene: Splicing of the intron in transgenic plants and its use in monitoring early events in Agrobacterium-mediated plant transformation. Mol. Gen. Genet. 220:245-250.

Zhang, Z. 1996. Development of transgenic plants with non-plant antibacterial protein genes for resistance to bacterial pathogens. PhD diss. Univ. of Nebraska, Lincoln. 